\title{
CYTOTOXIC ACTIVITY OF ACIDIC RIBOSOME INACTIVATING PROTEINS MIRABILIS JALAPA L. (RIP MJ-C) NANOPARTICLE FORMULATED WITH LOW-CHAIN CHITOSAN AND LOW- METHYLATED PECTIN
}

\author{
MONICA KRISTIANI ${ }^{1,2}$, SISMINDARI $^{*}{ }^{*}$, RONNY MARTIEN ${ }^{1}$, HILDA ISMAIL $^{1}$, AGUSTINUS YUSWANT0 ${ }^{1}$ \\ ${ }^{1}$ Faculty of Pharmacy Universitas Gadjah Mada, Yogyakarta, Indonesia, ${ }^{2}$ Pharmacy Academy, Theresiana, Semarang, Indonesia \\ Email: sismindari@ugm.ac.id
}

Received: 27 Feb 2017 Revised and Accepted: 19 Jun 2017

\begin{abstract}
Objective: This study aimed to formulate acidic ribosome inactivating protein isolated from Mirabilis jalapa L. (RIP MJ-C) nanoparticle, using low chains chitosan and low methylated pectin, and to evaluate its cytotoxic activity against T47D breast cancer cell line.

Methods: RIP MJ-C was isolated from Mirabilis jalapa L leaves using ion exchange chromatography method, and its presence was tested using super coiled double-stranded deoxyribonucleic acid (DNA) cleavage activity. The nanoparticle of RIP MJ-C was formulated using low chains chitosan and low methylated pectin. The optimum formula was characterised using transmission electron microscope (TEM) and particle size analyzer. The cytotoxic activity of the nanoparticle against T47D breast cancer cell-lines was assessed using MTT assay.

Results: The optimum formula was obtained at the combination of $0.06 \%$ low chain chitosan and $0.02 \%$ low methylated pectin. It was revealed that the nanoparticles have a particle size of $54.43 \pm 10.14 \mathrm{~nm}$, polydispersity index of $0.514 \pm 0.10$, and zeta potential of $+93.59 \pm 6.90 \mathrm{mV}$. The cytotoxic activity test showed that RIP MJ-C nanoparticles conjugated with anti-EpCAM 9C4 have the highest cell death percentage of 43.20\% compared to unformulated RIP MJ-C.
\end{abstract}

Conclusion: It was concluded that the RIP MJ-C nanoparticle conjugated with an anti-EpCAM antibody could enhance the cytotoxicity of RIP MJ-C against T47D breast cancer cell-lines.

Keywords: RIP MJ-C, Mirabilis jalapa L, Nanoparticle, Low-chain chitosan, Low-methylated pectin

(C) 2017 The Authors. Published by Innovare Academic Sciences Pvt Ltd. This is an open access article under the CC BY license (http://creativecommons.org/licenses/by/4.0/) DOI: http://dx.doi.org/10.22159/ijpps.2017v9i8.18171

\section{INTRODUCTION}

Mirabilis jalapa leaves were revealed to contain more than one ribosome inactivating proteins (RIP): RIP MJ-30 (basic RIP MJ) and MJ-C (acidic RIP MJ) [1-2]. Both of the RIPs have the ability to cleave supercoiled DNA into nick circular and linear form. It was found that RIP MJ-C has a more cytotoxic effect than RIP MJ-30 [3].

Therefore, RIP MJ-C could be developed as a potential anticancer agent. The challenge of RIP MJ-C delivery is that it could be easily degraded in the body and have potential difficulties in entering targeted cells [4-5]. Nanoparticle formulation would be one of the way to resolve these problems and improving protein activity against cancer cells [6-7]. Nanoparticles could be defined as colloidal particles with a size range of $10-1000 \mathrm{~nm}$, forming a polymer wall or as a whole is formed as a matrix formed by polymers [8]. Nanoparticles formulated using biopolymers such as chitosan has been known to increase the effectivity of various anticancer drug delivery [9]. Previous work indicated that nanoparticle designed from low chain chitosan and high methylated pectin showed good potential for improving unpurified RIP MJ activity against MCF7 breast cancer cell-line [10]. A similar result was also found from unpurified RIP MJ nanoparticle formulated by medium chain chitosan and high methylated as well as low chained chitosan and alginate $[11,12]$. Therefore, in this research, we explored the use of another formula using low chain chitosan and low methylated pectin as a delivery system for RIP MJ-C, a purified acidic RIP MJ protein

One of the ways to improve the selectivity and effectiveness of nanoparticle delivery system is by conjugating nanoparticles to molecules that could specifically reach target cancer cells. This was exemplified by conjugation of ribonucleic acid (RNA) A10 to poly (D,L-lactic-co-glycolic acid)-b-poly(ethylene glycol) (PLGA-b-PEG) nanoparticles containing cisplatin and dual-aptamer based doxorubicin delivery system for prostate cancer targeted therapy [13-15]. Other molecule target that might be used is epithelial cell adhesion molecule (EpCAM), a monomer membrane glycoprotein found within the normal human epithelium. EpCAM could serve as a molecular marker between cancer cells and normal cells since it was found to be over expressed on breast cancer cells [16]. By conjugating nanoparticle to an anti-EpCAM antibody, the toxic proteins or drugs would presumably be carried specifically into target cancer cells. Therefore, conjugation of anti-EpCAM antibody conjugation to RIP MJ-C nanoparticles could help carry RIP MJ-C to target cells without damaging the normal ones.

Cytotoxic test of conjugated unpurified RIP MJ nanoparticle to antiEpCAM AUA-1 against T47D breast cancer cells showed low cytotoxicity due to the low affinity of anti-EpCAM AUA-1 towards T47D cells [10]. Based on this finding, we found it necessary to formulate RIP MJ-C, a purified basic fraction of RIP MJ, with the use of low-chain chitosan and low-methylated pectin as nanoparticle and conjugate this formula with another kind of anti-EpCAM antibody, 9C4 to create a more effective and selective delivery system. The cytotoxic analysis was carried out in vitro against breast cancer T47D cell line.

\section{MATERIALS AND METHODS}

Plant materials

Fresh leaves of $M$. jalapa L (red flower cultivar) were collected from Yogyakarta, Indonesia. A voucher specimen was deposited in the Laboratory of Molecular Biology, Universitas Gadjah Mada, Yogyakarta, Indonesia. The breast cancer T47D cell-line was obtained from the stock of Life Science Laboratory, LPPT Universitas Gadjah Mada.

\section{Chemicals and reagents}

The chemicals and reagents used in this study are as follows: CMsepharose CL-6B (Sigma Aldrich), disodium hydrogen phosphate $\left(\mathrm{NaHPO}_{4}\right)$ (Merck), sodium dihydrogen phosphate $\left(\mathrm{NaH}_{2} \mathrm{PO}_{4}\right)$ 
(Merck), sodium chloride ( $\mathrm{NaCl})$ (Merck), magnesium dichloride $\left(\mathrm{MgCl}_{2}\right)$ (Merck), acetone (Merck), BioRad ${ }^{\circledR}$ reagent (Bio Rad), agarose (Invitrogen), blue phenol (Merck), ethylenediaminetetraacetic acid (EDTA) (Invitrogen), bovine serum albumin (Sigma Aldrich), short chain chitosan (Sigma Aldrich), low methylated pectin (Sigma Aldrich), tris (hydroxymethyl) aminomethane hydrochloride (tris $\mathrm{HCl}$ ) (Merck), sodium dodecyl sulfate (Merck), pUC19 DNA plasmid (Thermo Scientific), acetic acid glacial (Merck), sodium acetate $\left(\mathrm{CH}_{3} \mathrm{COONa}\right)$ (Merck), 9C4 anti-EpCAM antibody (Sigma Aldrich), 1-ethyl-3-(3-dimethylpropyl) carbodiimide hydrochloride (EDAC) (Sigma Aldrich), native polyacrylamide gel electrophoresis (native-PAGE) kit (Sigma Aldrich), fetal bovine serum (FBS) 10\% v/v (Gibco), penicillinstreptomicine 1\% v/v (Gibco), ethidium bromide (EtBr) (Merck), phosphate buffer saline (Sigma Aldrich), tris (hydroxymethyl) aminomethane borat ethylene-diamine tetraacetic acid (TBE) (Merck), and 3-(4,5-dimethyltiazol-2-il)-2,5-diphenyl tetrazolium bromide (MTT) (Sigma Aldrich). All ingredients used in this study were of analytical grade.

\section{Extraction and purification of RIP MJ-C from M. jalapa L}

Extraction and purification of RIP MJ from the leaves of M. jalapa L were carried out as described by Sismindari and Lord J. M. (2006) [17]. The protein was then applied to CM-sepharose CL-6B (Sigma-Aldrich) and eluted using $5 \mathrm{mmol}$ phosphate buffer $\mathrm{pH} 6.5$ for unbound fraction to get RIP MJ-C. The eluted fractions were collected every $2 \mathrm{~min}$ in micro tubes and were screened for supercoiled double stranded DNA cleavage activity as an indicator for RIP-like activity. The freeze-dried RIP MJ-C was then used for further analysis.

\section{Cleavage of supercoiled double stranded DNA activity by the protein extracts}

The supercoiled DNA cleavage activity was done to confirm the presence of RIP activity in the eluted protein fractions. The protein's cleavage activity towards supercoiled double stranded DNA was done by mixing $1 \mu \mathrm{g}$ of plasmid DNA pUC18 (obtained from stock of Molecular Biology laboratory, Faculty of Pharmacy Universitas Gadjah Mada) with various protein fractions to final volume of $10 \mu \mathrm{L}$ containing reaction buffer $\left(50 \mathrm{mmol}\right.$ Tris- $\mathrm{HCl}, 10 \mathrm{mmol} \mathrm{MgCl}_{2}, 100$ $\mathrm{mmol} \mathrm{NaCl}$ ) in $\mathrm{pH}$ 8.0. The mixture was incubated at $30{ }^{\circ} \mathrm{C}$ for $1 \mathrm{~h}$ followed by electrophoresis on a $1 \%(\mathrm{w} / \mathrm{v})$ agarose gel in $0.5 \mathrm{x}$ TBE buffer. DNA bands were visualised by ethidium bromide staining [1-2].

\section{Formulation of RIP MJ-C nanoparticle}

Nanoparticles were formulated using low chain chitosan and low methylated pectin with a concentration range of $0.07-0.1 \%$ and 0.01-0.02\% respectively and different amounts of RIP MJ-C (300, 150,100 and $50 \mu \mathrm{g}$ ) was added to each formula. The optimum formula was determined based on the turbidity (clear, cloudy, or opalescent) observation and measurement of transmittance and entrapment efficiency (EE) of nanoparticle [18]. Entrapment efficiency of RIP MJ-chitosan-pectin nanoparticles was measured by calculating the amount of added RIP MJ-C and the free RIP MJ-C in the supernatant. The separation was done by centrifugation and the free RIP MJ-C was determined using Bradford method [19]. The EE value of nanoparticles was calculated with the following equation:

Entrapment efficiency (\%) $=\frac{\text { amount of the total protein }- \text { amount of the free drug }}{\text { amount of the total protein }} \times 100 \%$

Percentage of transmittance was identified using UV-Vis spectrophotometer (Genesys ${ }^{\mathrm{TM}} 10 \mathrm{~s}$, US) at a wavelength of $650 \mathrm{~nm}$. Surface morphology of the optimum formulation was measured using TEM analyzer (JOEL JEC-560, Japan) at Faculty of Mathematics and Natural Sciences, UGM, Yogyakarta. In addition, the screening of optimal formula was also carried out theoretically using Design Expert $^{\circledR}$ software version 1.7.15 using $2^{2}$ factorial design method with two responses: percentage of transmittance and EE.

\section{Nanoparticles characterization}

The optimal formula of the nanoparticles was then characterized by measuring the value of, particle size, polydispersity index (PI) and zeta potential, as well as observation of its surface morphology. Average particle size, PI and zeta potential of optimal nanoparticles formula were determined using laser dynamic light scattering method (Delsa ${ }^{\mathrm{TM}}$ nano-submicron particle size and zeta potential analyzer, Beckman Coulter). The PI value indicates the size distribution of nanoparticles in a given sample. Zeta potential indicates the surface charge on the particles and was measured to determine the stability of nanoparticles in the solution [10].

\section{Conjugation of RIP MJ-C nanoparticle with anti-EpCAM 94C}

Conjugation of RIP MJ-C nanoparticle with anti-EpCAM 94C antibody was carried out using a carbodiimide catalyst (EDAC). RIP MJ-C nanoparticle formulas was dialysed using $50 \mathrm{kDa}$ dialysis membranes for $24 \mathrm{~h}$ at $4{ }^{\circ} \mathrm{C}$. Dialysed RIP MJ-C was mixed with EDAC solution using a vortex for $15 \mathrm{~m}$. The mixture was then added with anti-EpCAM antibody followed by stirring for $15 \mathrm{~m}$ at $4{ }^{\circ} \mathrm{C}$. Afterwards, the mixture was incubated for $24 \mathrm{~h}$ at $4{ }^{\circ} \mathrm{C}$, followed by another $24 \mathrm{~h}$ dialysis. The conjugation was done with the volume ratio of 5:1:0.5 for RIP MJ-C nanoparticle: anti-EpCAM 9C4 antibody: EDAC respectively.

\section{Cytotoxic test}

The cytotoxicity assay was carried out based on the method of Sismindari et. al (2010) with slight adjustment [20]. As much as 100 $\mathrm{ml}$ of the exponentially growing T47D cells $\left(5 \times 10^{4}\right.$ cells $\left./ \mathrm{ml}\right)$ were grown in 96 -well plate and starved for $24 \mathrm{~h}$ at $37^{\circ} \mathrm{C}$ in the presence of $5 \% \quad \mathrm{CO}_{2}$. Afterwards, a serial concentration of RIP MJ-C nanoparticle was added to the cells followed by $4 \mathrm{~h}$ incubation period. The number of viable cells was ascertained through MTT assay and measured at $\lambda_{550} \mathrm{~nm}$.

\section{RESULTS AND DISCUSSION}

\section{Preparation of RIP MJ-C}

The extraction and purification of RIP MJ-C from fresh M. jalapa leaves resulted in $0.15 \%$ amount of proteins. The obtained proteins had RIP activity as demonstrated by their ability on cleaving supercoiled double stranded DNA into nick-circular and linear form (fig. 1A). A similar result was also obtained from the lyophilized RIP MJ-C as shown at fig. 1B. Higher concentration of RIP MJ-C showed better ability to cleave supercoiled double stranded DNA.

This result indicated that the isolated RIP MJ-C stayed stable and kept its activity following the lyophilization process. These result supported previous research which indicated that protein fraction containing RIP MJ and RIP MJ-C was able to cleave supercoiled DNA, and the cleavage activity could still be detected on RIP MJ following lyophilized process $[1,2,12,21]$.

\section{Optimization of RIP MJ-C nanoparticle formula}

Visual screening based on the turbidity of the nanoparticle was done using various combination of low chained chitosan and low methylated pectin in the range of $0.04 \%-0.1 \%$ and $0.1 \%-0.04 \%$ respectively. Four formulas with the combination of $0.06 \%-0.09 \%$ short chained chitosan and 0.01\%-0.02\% low-methylated pectin was chosen based on their stability (no precipitation formed after $7 \mathrm{~d}$ ) as shown in table 1.

Transmittance and EE of the four selected formulas was then measured following the visual screening. The result indicated that the highest EE value obtained was $59.44 \%$, whereas for the highest transmittance value was $83.2 \%$ (table 2). The optimum nanoparticle obtained was formulated with the combination of $0.06 \%$ short-chain chitosan and $0.02 \%$ low-methylated pectin.

This might be caused by the fact that when the chitosan concentration was low, it caused the chitosan fibres to become tight which could result on greater free space within the nanoparticle for proteins to be trapped inside. This means that more RIP MJ-C could be entrapped inside of the nanoparticle. These results were supported by the calculated data of EE and transmittance screening, which was carried out using Design Expert as shown in fig. 2 and fig. 3. 

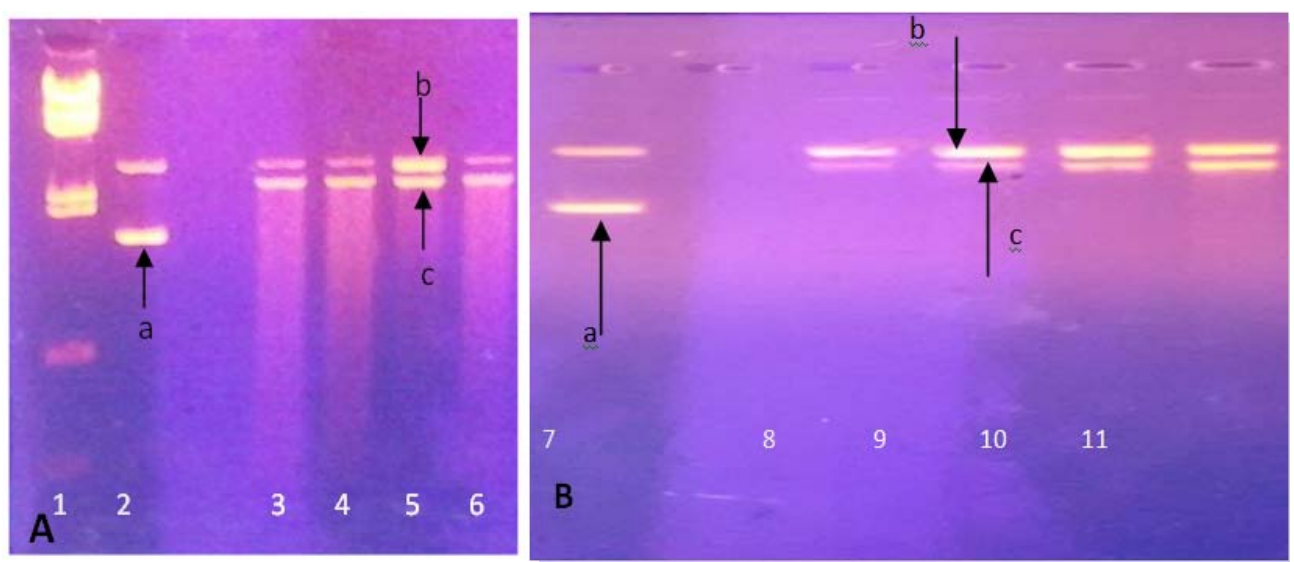

Fig. 1: The supercoiled DNA cleavage activity of RIP MJ-C. The DNA supercoiled cleavage activity was carried out on RIP MJ-C (A) and lyophilized RIP MJ-C (B). Lane 1 is $\lambda_{\text {HindIII }}$ DNA marker, lane 2 and 7: untreated pUC19; lane 3-6 pUC19 treated with RIP MJ-C; lane 8-11 pUC19 treated with various amount of lyophilized RIP MJ-C. The active protein will cleave supercoiled DNA (a) to become nick circular form (b) and linear form (c). The visualization of the results was done on $0.8 \%$ agarose gel electrophoresis

Table 1: Visual screening of nanoparticle formulated using various combination of low chain chitosan and low methylated pectin. Note: $(-)=$ clear, no precipitation, (o) = opaque, $\downarrow$ = small precipitation, $\downarrow \downarrow$ = higher amounts of precipitation

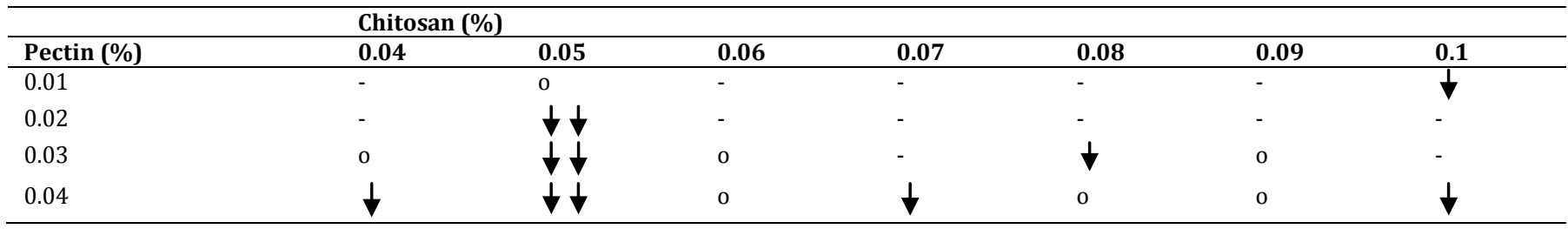

Table 2: Transmittance and EE value of the four formula chosen from visual screening, Data shown as mean $\pm \mathrm{SD}, \mathrm{n}=3$

\begin{tabular}{lll}
\hline Formula & Transmittance (\%) & Entrapment efficiency (\%) \\
\hline Chitosan $0.06 \%$ & $82.2 \pm 0.36$ & $52.67 \pm 1.69$ \\
Pectin $0.01 \%$ & $83 \pm 0.2$ & $59.44 \pm 3.8$ \\
Chitosan $0.06 \%$ & & \\
Pectin $0.02 \%$ & $84 \pm 0.2$ & $34.18 \pm 4.6$ \\
Chitosan $0.09 \%$ & $82.9 \pm 0.1$ & $32.32 \pm 3.07$ \\
Pectin $0.01 \%$ & & \\
Chitosan $0.09 \%$ & & \\
\hline
\end{tabular}
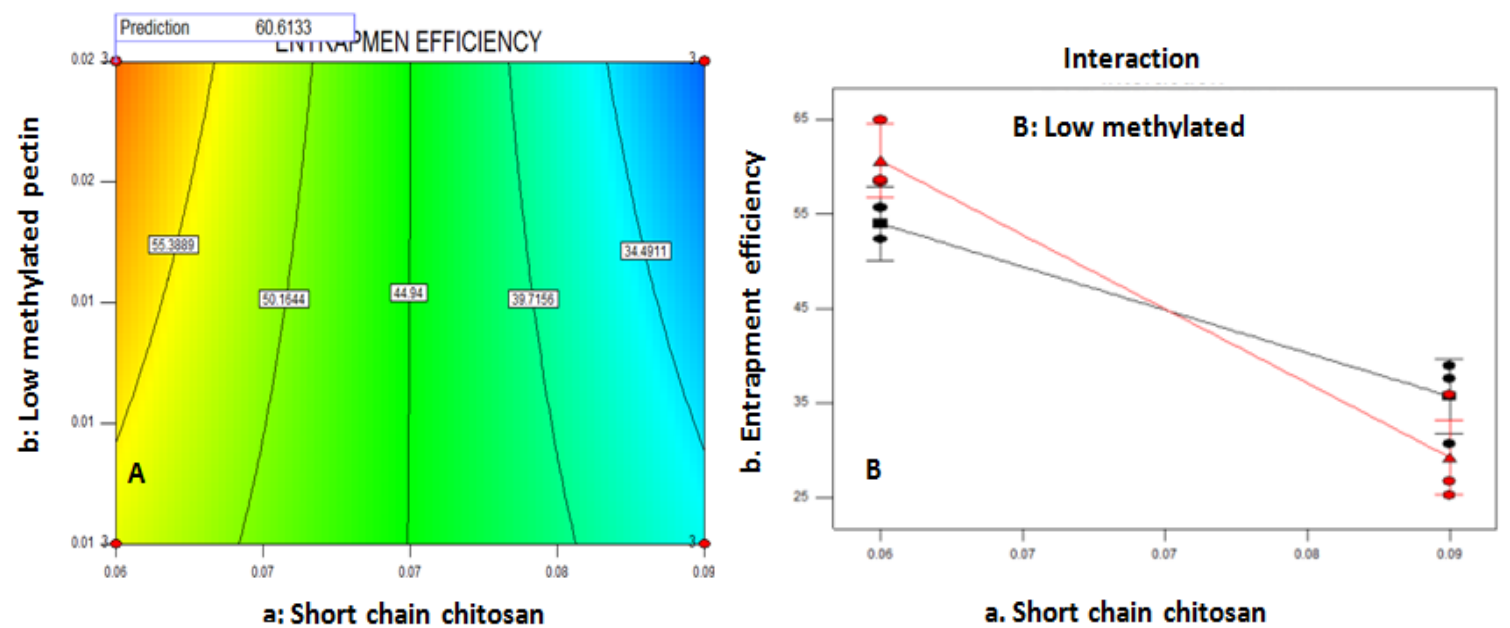

a. Short chain chitosan

Fig. 2: Screening (using Design Expert version 7.1.5.) for the optimum formula of short chain chitosan and low methylated pectin based on EE value. Four different combinations of chitosan and pectin were used for the formula: $0.06 \%$ chitosan $(C)+0.01 \%$ pectin $(P) ; 0.06 \%$ $\mathrm{C}+0.02 \% \mathrm{P} ; 0.09 \% \mathrm{C}+0.01 \% \mathrm{P}$; and $0.09 \% \mathrm{C}+\mathbf{0 . 0 1} \% \mathrm{P}$. Based on the contour plot of effect $(\mathrm{A})$ and interaction profile (B), low concentration of chitosan and high concentration pectin showed correlation to increasing $E E$ value 

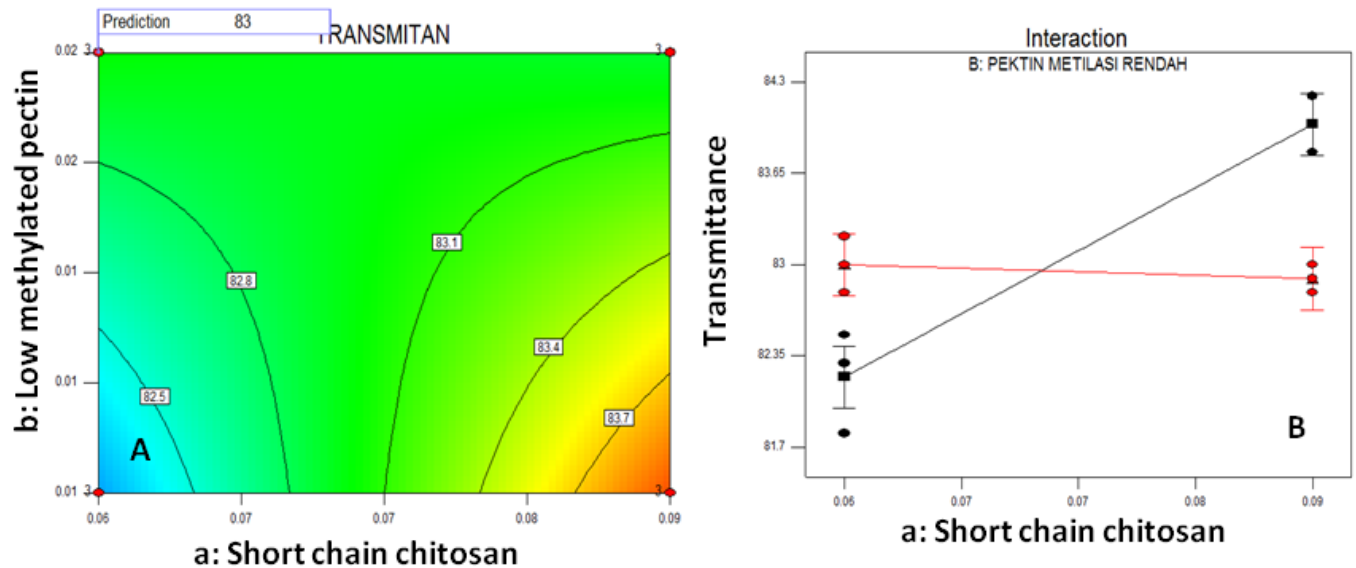

Fig. 3: Identification of transmittance value for optimum formula screening (using Design Expert version 7.1.5.) of short chain chitosan and low methylated pectin. Four different combination of chitosan and pectin were used for the formula: $0.06 \%$ chitosan (C)+0.01\% pectin (P); $0.06 \% \mathrm{C}+0.02 \% \mathrm{P} ; 0.09 \% \mathrm{C}+0.01 \% \mathrm{P}$; and $0.09 \% \mathrm{C}+0.01 \% \mathrm{P}$. Based on the contour plot of effect (A) and interaction profile (B), low concentration of chitosan and high concentration pectin showed correlation with increasing transmittance value

Based on the contour plot data on EE calculation (fig. 2A) and interaction profile (fig 2B), it was shown that the higher concentrations of short chain chitosan and low methylated pectin, the smaller of the value of resultant X.

From the interaction profile in fig. 3B, the equation associated with the response of the transmittance is as follows:

$$
\mathrm{Y}=83.03+0.42 \mathrm{Xa}-\mathrm{Xb} \text { 0.075-0.47 XaXb. }
$$

$\mathrm{Xa}$ and $\mathrm{Xb}$ indicated short chain chitosan and low methylated pectin respectively. Notation positive $(+)$ and $(-)$ in the equation indicated the increase and decrease of the transmittance value respectively.

Based on the coefficient value, it can be seen that the concentration of short chain chitosan has a greater influence on the transmittance compared to the low methylated pectin. The interaction between short chain chitosan and low methylated pectin is characterised by the coefficient of- 0.47 which shows a decrease of the transmittance value.

\section{Characteristics of RIP MJ-C nanoparticles}

The chosen optimum formula of RIP MJ-C nanoparticle was then characterized by identifying the particle size, PI, zeta potential, and its surface morphology. The result indicated that the nanoparticle had average particle size of $54.43 \pm 12.4 \mathrm{~nm}$, PI of $0.514 \pm 0.1$, and zeta potential of $+93.59 \pm 6.9 \mathrm{mV}$. The particle size result showed that the result of the formulation was indeed nanoparticle since molecule can be identified as nanoparticles when it has a particle size between 10$1000 \mathrm{~nm}$ [16]. The size of the nanoparticles is affected by the concentration of active ingredients, type of polymers used in the formulation, the speed of cross-linked material addition and stirring speed during formation [15].

The particle size can affect drug release and stability of nanoparticles. The resulted nanoparticle was uniformly distributed, as indicated by the PI value. The Higher PI value indicates a wide distribution of nanoparticles which could results in the formation of aggregates as well as low stability and homogeneity of the suspension. When PI value is below 0.7, the particle size is considered to be evenly distributed [22]. The zeta potential provided an overview of the charges on the particle surface. Previous findings indicated that stability of nanoparticles could be reached when the suspension's zeta potential are valued below $-30 \mathrm{mV}$ or above +30 $\mathrm{mV}$. The Greater zeta potential of particles in colloids indicates higher repulsive force among particles which would make it more difficult for the particles to form aggregates [23].

The three-dimensional characterization of RIP MJ-C nanoparticle surface morphology was carried out using TEM (fig. 4). The formed nanoparticles have a spherical shape and no aggregation were found among the particles. A spherical form of the particle could facilitate contact between particles and formation of aggregates, causing the increase of the particle size and instability of nanoparticle suspension [24-25].

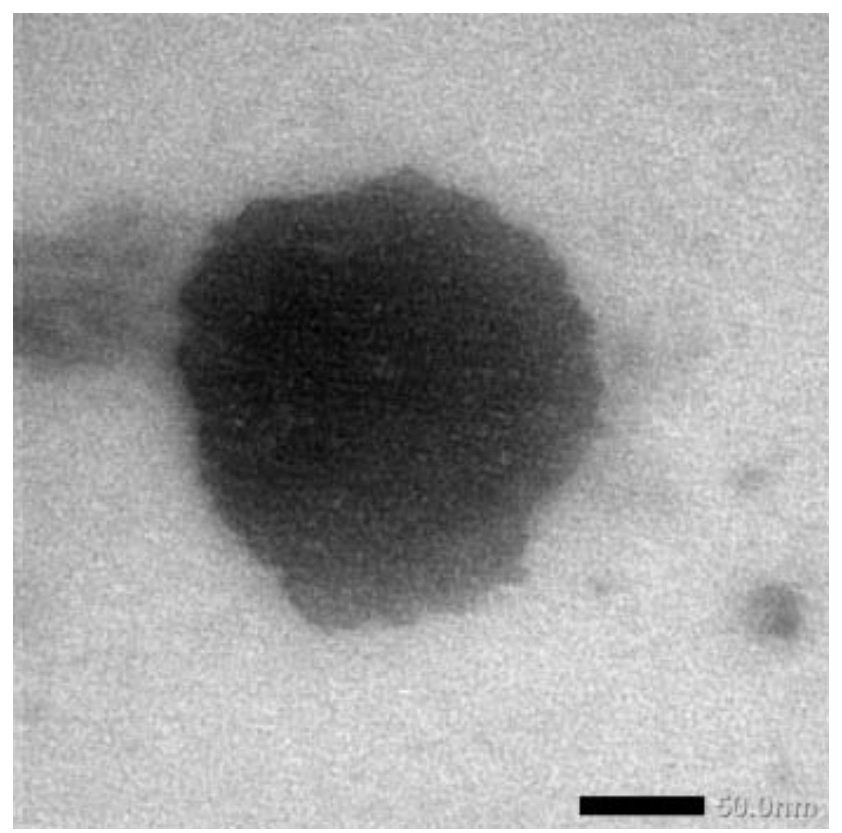

Fig. 4: Surface morphology of RIP MJ-C nanoparticle seen through transmission electron microscopy (TEM). The nanoparticles have spherical shapes and did not form aggregates

\section{Cytotoxicity of 9C4 anti-EpCAM antibody conjugated RIP MJ-C nanoparticle}

In order to improve the effectiveness, efficiency and safety of the protein, the optimum RIP MJ-C nanoparticle was conjugated with anti-EpCAM 9C4 antibody [10]. The conjugation process was done using EDAC through carbodiimide reaction. EDAC works by activating the free carboxylate groups in the antibody and make it more reactive to form an amide bond with free amine groups found in the surface of the nanoparticle. Cytotoxic analysis of the conjugated formula was then carried out against T47D breast cancer cell-lines.

The result as shown in fig. 5 indicated that the conjugated RIP MJ-C nanoparticle at the highest concentration $(16.67 \mu \mathrm{g} / \mathrm{ml})$ could inhibit the growth of the T47D cell-lines by $32.49 \%$, while 
unconjugated RIP MJ-C nanoparticles at the same concentration could inhibit it by $24.60 \%$. Both the conjugated and unconjugated RIP MJ-C nanoparticle showed higher cytotoxic activity compared to the unformulated RIP MJ-C which was only able to inhibit $13.9 \%$ of T47D cell growth. These results supported previous work, where the inhibition activity of unpurified RIP MJ against T47D cell-lines was increased by nano particle formulation [12]. This result also showed that the 9C4 anti-EpCAM antibody was more selective towards T47D cell lines compared to AUA1 anti-EpCAM antibody which was used in the study of Wicaksono, et al. (2016) [12].

Based on the results of the cytotoxic assay, it can be concluded that nanoparticle formulation and conjugation of anti-EpCAM antibody could increase the cytotoxic activity of RIP MJ-C. Generally, the percentage of cell death showed to be increasing along with the concentration increase of both unconjugated and conjugated RIP MJC nanoparticles as well as the unformulated RIP MJ-C. This phenomenon also indicated a dose-dependent fashion in RIP MJ-C's cytotoxic effect.

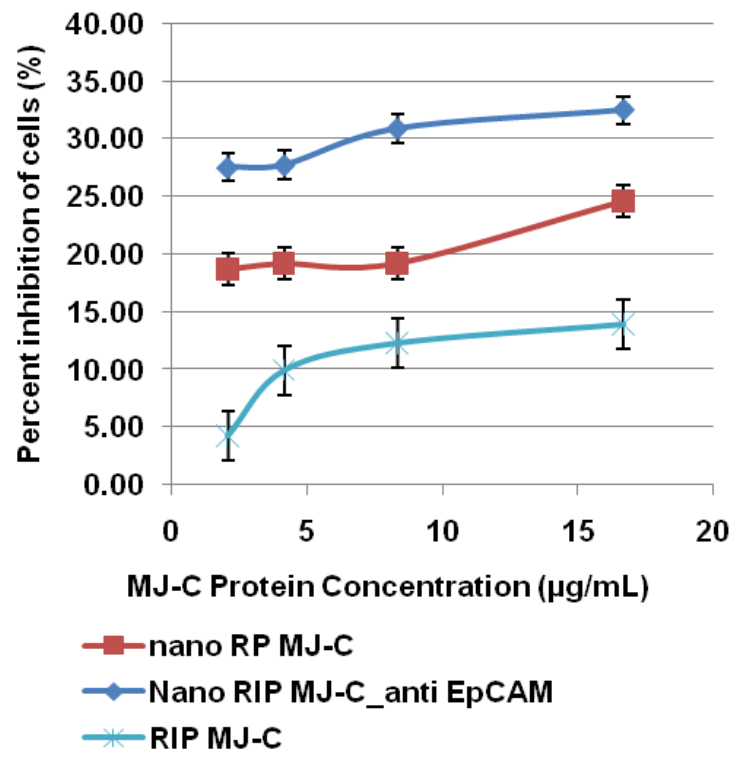

Fig. 5: Graph of the cytotoxic test against cancer cells T47D. The incubation period was for $4 \mathrm{~h}$ after treatment. Data points represents mean $\pm S D, n=4$

\section{CONCLUSION}

The optimum RIP MJ-C nanoparticle was formulated using $0.06 \%$ short chain chitosan and $0.02 \%$ low methylated pectin, resulting in nanoparticles with a particles size of $54.43 \mathrm{~nm}$, polydispersity index value of 0.514 and zeta potential of $+93.59 \mathrm{mV}$. The RIP MJ-C nanoparticle could then be conjugated with an anti-EpCAM 9C4 antibody with the use of EDAC through carbodiimide reaction. Both the nanoparticle formulation and the conjugation of anti-EpCAM antibody could increase the cytotoxic activity of RIP MJ-C against breast cancer cell line T47D.

\section{ACKNOWLEDGEMENT}

This research was supported by PUPT UGM 2016, No. 015/SP2H/LT/DRPM/II/2016, with the research team of Sismindari, Hilda Ismail, Ronny Martien and Agustinus Yuswanto. We would like to thank Dewa Ayu Arimurni and Wahyudi MDP for technical assistance.

\section{AUTHOR CONTRIBUTION}

Monica Kristiani collected the data and performed the anlaysis, as her Master Thesis. Sismindari, Hilda Ismail, Agustinus Yuswanto and
Ronny Martien designed the study, developed the methodology and contributed to data analysis and interpretation.

\section{CONFLICTS OF INTERESTS}

All authors have none to declare

\section{REFERENCES}

1. Ikawati Z, Sudjadi, Sismindari. Cytotoxicity against tumor cell lines of ribosome-inactivating protein (RIP)-like protein isolated from Mirabilis jalapa L. Malays J Pharm Sci 2006;4:1-11.

2. Sudjadi, Sismindari, Herawati T. Purification of ribosome inactivating protein (RIP) from Mirabilis jalapa L. leave with CM-sepharose CL-6B and Seph acryl S-300HR column. Indonesian J Pharm 2003;2:316-21.

3. Sudjadi, Witasari LD, Sadarum MT, Nastity N, Sismindari. Cytotoxic effect of protein such as ribosome inactivating protein (RIP) acid from Mirabilis jalapa L. leaves against cancer cells. Indonesian J Pharm 2007;1:8-14.

4. Citores L, Iglesias R, Ferreras J. Ribosome inactivating proteins from plants: biological properties and their use in experimental therapy in antitumor potential and other emerging medical properties of natural compounds. New York: Springer; 2013. p. 127-43.

5. De Virgilio M, Lombardi A, Caliandro R. Ribosome-inactivating proteins: from plant defence to tumor attack. Toxins 2011;2:2699-737.

6. Lankalapalli S, Kollapal V. Polyelectrolyte complexes: a review of their applicability in drug delivery technology. Indian J Pharm Sci 2009;71:481-7.

7. Leon L, Carvalho ELS, Seijo B, Ortega-Vinuesa JL, BastosGonzález D. Physicochemical characterization of chitosan nanoparticles: electro-kinetic and stability behavior. J Colloid Interface Sci 2005;283:344-51.

8. Rawat M, Singh D, Saraf S, Saraf S. Nanocarriers: a promising vehicle for bioactive drugs. Biol Pharm Bull 2006;29:1790-8.

9. Shaima C, Moorthi PV, Kutty SN. In vitro anticancer activity of $5^{\prime}$ fluo uracil coated chitosan nanoparticle. Int J Curr Pharm Res 2016;8:6-8.

10. Pertiwi D, Martien R, Sismindari, Ismail H. Nanoparticle formulation of targeted ribosome inactivating protein Mirabillis jalapa (RIP MJ) using pectin-chitosan short chains conjugated by antibody anti-EpCAM and cytotoxic test against breast cancer cells. Pak J Pharm Sci 2017. Article In Press.

11. Feranisa A, Arimurni DA, Ismail H, Martien R, Sismindari. Formulation of medium viscosity chitosan-pectin-mj protein nano particles conjugated with anti-EpCAM and its cytotoxicity against T47D breast cancer cell lines. Int J Biotech 2015;20:1-10.

12. Wicaksono PA, Sismindari, Martien R, Ismail H. Formulation and Ribosome inactivating protein Mirabilis jalapa L (RIP-MJ) nanoparticles cytotoxicity test using the low viscosity of alginate-cytosan conjugated by antibody anti-epcam againts T47D cells. Asian Pac J Cancer Prev 2016;17:2277-84.

13. Dhar S, Kolishetti N, Lippard SJ, Farokhzad OC. Targeted delivery of a cisplatin prodrug for safer and more effective prostate cancer therapy in vivo. Proc Natl Acad Sci U S A 2011;108:1850-5.

14. Min K, Jo H, Song K, Cho M, Chun, Jon S. Dual-aptamer-based delivery vehicle of doxorubicin to both PSMA (+) and PSMA (-) prostate cancers. Biomaterials 2011;32:2124-32.

15. Ozalp VC, Eyidogan F, Oktem HA. Aptamer-gated nanoparticles for smart drug delivery. Pharmaceuticals 2011;4:1137-57.

16. Osta W, Chen Y, Mikhitarian K, Mitas M, Salem M, Hannun Y. EpCAM is overexpressed in breast cancer and a potential target for breast cancer gene therapy. Cancer Res 2004;64:5818-24.

17. Sismindari, Lord JM. The rna-n-glycosidase activity of leaves crude extract from Carica papaya, Morinda citrifolia, Mirabilis yalapa. Int J Biotech 2000;Suppl:342-5.

18. Martien R, Adhyatmika, Irianto DI, Farida V, Purwita SD. Development of nanoparticles technology as drug release system. Indonesian J Pharm 2012;3:1-5.

19. Nobel A. Quick Start ${ }^{\mathrm{TM}}$ bradford protein assay instruction manual. Hercules (CA): Bio-Rad Laboratories; 2000.

20. Sismindari, Hartati MS, Adhyatmika. Cytotoxic selectivity of $\mathrm{MJC}_{0.3}$ and $\mathrm{MJC}_{0.5}$, acidic ribosome-inactivating proteins 
isolated from Mirabilis jalapa L. leaves against various cancer cell-lines. J Med Sci 2010;42:39-43.

21. Ling J, Liu W, Wang TP. Cleavage of supercoiled doublestranded DNA by several ribosome-inactivating proteins in vitro. FEBS Lett 2009;345:143-6.

22. Nidhin M, Indumathy R, Sreeram KJ, Nair BU. Synthesis of iron oxide nanoparticles of narrow size distribution on polysaccharide templates. Bull Mater Sci 2008;31:93-6.

23. Mohanraj V, Chen Y. Nanoparticles: a review. Trop J Pharm Res 2006;1:561-73.

24. Tiyaabonchai W. Chitosan nanoparticles: a promising system for drug delivery. Naresuan University J 2003;2:51-66.
25. Adhyatmika (Thesis). Preparation of pentagamavunon-0 nanoparticles using matrix polymer of moderate chains chitosan and natrium tripolyphosphate cross-hook through ionic gelation mechanism as an anti-inflammation drug candidate. Yogyakarta: Universitas Gadjah Mada; 2012.

\section{How to cite this article}

- Monica Kristiani, Sismindari, Ronny Martien, Hilda Ismail, Agustinus Yuswanto. Cytotoxic activity of acidic ribosome inactivating proteins mirabilis jalapa L. (Rip MJ-C) nanoparticle formulated with low-chain chitosan and low-methylated pectin. Int J Pharm Pharm Sci 2017;9(8):69-74. 